\title{
The Anti-Cancer League and public outreach for cancer control in Peru
}

\author{
A Liga Anticancerosa e \\ a sensibilização pública \\ ao controle do câncer na \\ sociedade peruana
}

\author{
Raúl Necochea López ${ }^{i}$ \\ 'Associate Professor, Department of Social Medicine/ \\ University of North Carolina. \\ Chapel Hill - NC - USA \\ orcid.org/0000-0002-6242-5130 \\ raul_necochea@med.unc.edu
}

Received on 5 June 2019.

Approved on 27 Nov. 2019.
NECOCHEA LÓPEZ, Raúl. The AntiCancer League and public outreach for cancer control in Peru. História, Ciências, Saúde - Manguinhos, Rio de Janeiro, v.27, supl., set. 2020, p.49-69.

\section{Abstract}

Peru's first cancer control public outreach scheme started in the 1910s, but ground to a standstill as it attained official governmental recognition in 1926 as the Liga Anti-Cancerosa (LAC). This paper explains the developments leading to that earliest effort to enlist a coalition of State health agencies, physicians, and lay people in a campaign to publicize early signs of this disease, as well as the medical and political reasons for and implications of its decline. Besides highlighting the importance of professional initiatives shaping cancer activism, contextualizing the rise and fall of the LAC calls attention to the effects that hospitalization of cancer treatment had on aspects of cancer care that were not directly treatment-related, such as public outreach.

Keywords: cancer; Peru; surgery; radiology; public outreach.

\section{Resumo}

O primeiro programa peruano de sensibilização pública para controle do câncer iniciou na década de 1910, mas arrefeceu quando reconhecido pelo governo como Liga Anticancerosa (LAC), em 1926. Este artigo aborda os avanços que conduziram aos pioneiros esforços de recrutamento de agências governamentais de saúde, médicos e leigos na divulgação sobre os primeiros sinais da doença, assim como as motivações políticas e médicas e as implicações de seu declínio. Além de assinalar a importância de iniciativas profissionais no ativismo na temática do câncer, a contextualização da ascensão e declínio da LAC chama a atenção para os reflexos da hospitalização no tratamento do câncer sobre aspectos indiretamente relacionados ao tratamento, como os esforços de sensibilização pública.

Palavras-chave: câncer; Peru; cirurgia; radiologia; sensibilização pública. 
$I^{\prime}$ a 1922 letter to the editor of London's Pall Mall Gazette and Globe, Peruvian physician Juan José Mostajo addressed the shortcomings of Britain's cancer control efforts. "In spite of intense labor, the causes of cancer still remain unknown," Mostajo wrote, adding "nor have the labors begun twenty-five years ago by the Imperial Cancer Research Fund, and still proceeding under the able direction of Dr. [James Alexander] Murray resulted in any appreciable advance being made" (Salomón, 14 July 1922). Mostajo was in London as part of a long trip through Latin America, Europe, and the United States to gauge how different governments and organizations tackled the threat of cancer. Like other Peruvian physicians at the time, he supported enrolling a broad coalition of State health agencies, physicians, and lay people in campaigns to broadcast the early signs of the disease. This paper focuses on such public outreach, a topic which is drawing more attention (Buschini, 2014; Carrillo, 2010; Teixeira et al., 2007) among the multifaceted historiography of cancer in Latin America (Lana, 2016; Eraso, 2014; Cuperschmid et al., 2014; Teixeira et al., 2011; Andrade et al., 2010; Eraso, 2010; Mejía, 2008).

As Ornella Moscucci has shown, at the time of Mostajo's travels Britain did not favor widespread public engagement as an element of its anti-cancer efforts, focusing instead on the development of research institutions (Moscucci, 2016; Cantor, 2008). The approach was different in the United States, where Mostajo observed the nimble American Society for the Control of Cancer (ASCC) in New York City, which raised funds and promoted educational films and articles in popular magazines (Gardner, 2006). Impressed, Mostajo called the ASCC "the most perfect" of all the organizational efforts he witnessed during his two-year voyage. As if to underscore the salutary role of a well-informed public, he contrasted the American and British populations and pitied "the legion of English citizens crowding the doors of the hotel where I stayed [in London], asking me if this lesion or that sensation might be cancerous. Had I been a charlatan, I would have become rich" (Mostajo, 1945, p.4).

Had Mostajo waited a few years, he would have had to explain how the effervescence surrounding Peru's first cancer control public outreach scheme ground to a halt just as it attained governmental recognition in 1926 as the Liga Anti-Cancerosa (AntiCancer League, LAC). Public outreach for cancer control began again in the late 1930s within the Instituto Nacional del Cáncer (INC), but sidelined the LAC and weakened its plan of action. How did this dismissal come about? In this story, the hospital-based concentration of cancer treatment in the 1930s led the INC to view the non-hospitalbound LAC as extraneous and consequently disregarded it. Scholars such as John Pickstone have portrayed the evolution of cancer treatment in the twentieth century as a series of "contested cumulations" of path-dependent surgical, then radiological, then chemotherapeutic interventions that were negotiated in different historical circumstances, particularly in Britain and the United States. Peru's case not only extends the geographical reach of this concept but asserts the central role of the INC in debates about cancer control even before its establishment, and also elucidates the relevance of the "contested cumulations" framework to understand aspects of cancer care (such as public outreach) that are not directly treatment-related. 
The rise of the LAC in the 1920s owed much to the governmental institutionalization of medical surveillance in 1903, consolidation of the professional power of physicians at the Facultad de Medicina de Lima, and the patronage of President Augusto B. Leguía. But the LAC stalled in the late 1920s as Leguía fell and the notion of cancer as an illness requiring complex forms of clinical intervention gained strength. This view of cancer as a disease requiring hospital-based care by the 1930s allowed older surgical and newer radiology specialists to work somewhat harmoniously, building on earlier traditions of collegiality and resource-sharing, at least for a while. The hospitalization of treatment, however, also affected the LAC's public outreach for cancer, creating strong pressures to bring this function under the purview of the Ministry of Health-run INC, which was launched in 1939. The INC was unable to absorb all of the LAC's initiatives, squandering its accumulated experience and resources, and wound up relegating public outreach to a subordinate status within its bureaucracy, something its leaders would notice and lament in the 1940s as they struggled to explain their re-launch of public outreach efforts.

\section{Cancer and the Peruvian public in the early twentieth century}

Theorizing about cancer was not new in the Peruvian academic medical circles of the early twentieth century. Physicians like José Manuel Valdés, Pablo Petit, and José Manuel Dávalos discussed their cases abundantly between the early eighteenth and nineteenth centuries (Jouve, 2014). For the most part, however, doubt surrounded the etiology, natural history, and therapeutics of this illness (Denegri, 1895). To compound this uncertainty, various proprietary treatments were available for sale and advertised in well-known periodicals such as El Perú Ilustrado. These cure-alls included an elixir sold by Doctor Cazenave which, in addition to curing cancer, promised to cure syphilis, psoriasis, and tuberculosis; there was also Chapoteaut's Peptone Wine, which presumably restored the energy of those being treated for cancer (Advertisement, 1889a, 1889b).

An important change took place in 1895 with the appointment of Paris-trained Doctor Constantino T. Carvallo to the newly established Professorship of Gynecology at the Facultad de Medicina (García Calderón, 22 June 1897). With Carvallo at the helm, gynecology at San Marcos became a surgery-intensive specialty, at a time when radical heroic surgery was on the rise elsewhere (Aronowitz, 2007; Bastian, 1899). Carvallo set up a general surgery clinic at the 10-bed La Merced ward of the Santa Ana women's hospital and detailed the operations he performed and his lessons on cancer surgery. Hysterectomies became a common gynecological procedure in his clinic, and were prescribed for a wide variety of diagnoses, most commonly uterine fibroids, endometrial infections, uterine prolapses, and uterine cancers (Carvallo, 11 Dec. 1905, 19 Dec. 1898). Carvallo (6 Dec. 1906) was impressed by the dedication of the advanced medical students who joined him to witness these interventions, and waxed optimistic about his outcomes, noting that only two of his patients died on the operating table up to 1906. At the same hospital, Doctor Juvenal Denegri carried out the first radical mastectomy on a breast cancer patient in 1903, "successfully" in his opinion, as well as hysterectomies 
and tongue amputations (for uterine and tongue cancers, respectively) between 1904 and 1906 (Denegri, 1907).

Some physicians, however, were concerned about the number of women who died following post-operative infections, and about patients whose cancers returned because surgeons could not (or would not) distinguish the cases in which surgery was futile (Graña, 2001). Even so, gynecological clinics were important learning environments for the first generation of locally trained surgeons, who absorbed two crucial lessons. The first was that early interventions could curb cancer's tendency to return (Villarán, 1906). The second was that, given surgery's immature status in the local medical sphere, young surgeons "could not limit their work to a single ward or hospital; we all must work everywhere we could" to make surgery a better-known option (Mimbela, 1922, p.222). Motivated to boost the profile of their specialty, a group of seventeen surgeons founded the Sociedad Peruana de Cirugía (SPC) in 1918 and elected Carvallo to be its first president (Academia..., 1984).

As the attractiveness of surgery extended beyond the Facultad de Medicina, practitioners sought to tighten their control over it. Popular reliance on non-allopathic healers (particularly Chinese ones) posed a formidable challenge because Chinese herbalists had been attracting patients since the 1860s, long before the emergence of the SPC; their reputation for treating sexually transmitted illnesses, their relatively painless methods, and lower fees, combined with well-placed ads and patient testimonials, attracted the opprobrium of their competitors, particularly at the Facultad de Medicina. In the early twentieth century, this latter group waged a fierce but losing battle against these Chinese healers, accusing them of incompetence, greed, and (more specific to our case) practicing surgery in cases of cancer when, according to Peruvian physicians, they were at best simple merchants of medicinal plants (Palma, 2018).

Constantino T. Carvallo himself became embroiled in this fight when he berated the family of Delia Rodríguez for allowing her to be treated by Chau San San; according to Carvallo, this robbed him of time to operate successfully. When he reached Rodríguez's bedside in August of 1914, he saw what he described as "an enormous sarcoma-like tumor" on her thigh that had already been operated on. Noting the visible surgical incision, Carvallo (22 Aug. 1914) added that "the wound was dirty, suppurating, and was covered in a disgusting black resin, which, the family informed me, had been applied by a Chinese man." Carvallo declined to intervene any further, and Delia Rodríguez returned to see Chau San San after Carvallo's visit. She died a few days later, under San's care, as the Chinese healer told the police (San, 22 Aug. 1914).

Rodríguez's choice to remain under the care of Chau San San grimly illustrates the idiosyncratic logic of harm avoidance in cancer patients. Cancer sufferers recognized how difficult it was to halt their painful symptoms, and physicians knew patients could not be easily duped into optimism. As acknowledged by Doctor Juvenal Denegri, a founding member of the SPC, "one of the most powerful weapons of the physician, the white lie, has no effect whatsoever in advanced cancer cases" (Denegri, 1907, p.19). Surgeons at the time had little success alleviating the horrific long-term pain of cancer 
and its disabling effects. On the contrary, given the radical interventions proposed by surgeons, the immediate effect of surgery was to maim and harm. The frequent outcome of these intersecting factors was a last-resort hospital visit in which shocked and powerless physicians witnessed the overall wasted state of patients admitted for cancer, and then blamed these patients for their "careless obduracy" in refusing to seek medical care sooner (Odriozola, 1905, p.560). Considering this outlook, some entrepreneurial surgeons began to consider broadcasting the ubiquity and treatability of cancer as part of their professional duties.

\section{The Anti-Cancer League rises}

Between 1913 and 1930, the Sociedad de Beneficencia de Lima ${ }^{1}$ produced detailed statistics on all the establishments it managed, which included the largest and most important hospitals in the capital: Hospital Dos de Mayo, Hospital de Santa Ana (for women, replaced in 1925 by the Hospital Arzobispo Loayza), Hospicio de Insanos (for mental afflictions), Hospicio de Incurables (for a broad range of cases considered incurable), Hospicio de Huérfanos Lactantes (for foundlings), and Lazareto de Variolosos (for smallpox patients) (Rabí Chara, 2006). The Beneficencia's statistics do not allow us to estimate how effective treatment at its hospitals was, nor specific mortality resulting from certain illnesses. But these statistics can still be used to reconstruct a picture of the combined morbidity and mortality of the most significant health threats in the capital by 1918 , the year surgeons founded the SPC.

Table 1: Morbidity and mortality by illness at Sociedad de Beneficencia de Lima hospitals

\begin{tabular}{|c|c|c|c|c|c|c|}
\hline Year & $\begin{array}{c}\text { Total morbidity } \\
\text { and mortality }\end{array}$ & Malaria & Tuberculosis & Syphilis & Pneumonia & $\begin{array}{c}\text { Diarrea/ } \\
\text { enteritis }\end{array}$ \\
\hline 1913 & 16,297 & 2,032 & 960 & 298 & 369 & 304 \\
\hline 1914 & 26,300 & 2,802 & 1,922 & 710 & 395 & 285 \\
\hline 1915 & 15,409 & 1,859 & 948 & 328 & 241 & 242 \\
\hline 1916 & 15,619 & 2,189 & 1,162 & 303 & 319 & 236 \\
\hline 1917 & 16,217 & 2,195 & 1,148 & 417 & 320 & 191 \\
\hline
\end{tabular}

Source: Boletín de Estadística de la Sociedad de Beneficencia Pública de Lima, 1913-1917

A cursory glance at these numbers reveals where the gravest health concerns lay. Although the incidence of cancer in Lima hospitals did not approach that of malaria, tuberculosis, syphilis, pneumonia, or diarrheic illnesses, cancer was nonetheless counted and broken down by the affected organ (see Table 2), an epidemiologically significant fact. Furthermore, unlike other illnesses, the Beneficencia calculated the mortality rate for various cancers, and showed that it was most common and most lethal in cases affecting the female reproductive system (see Table 3). 
Table 2: Morbidity and mortality of cancer at Sociedad de Beneficencia de Lima hospitals

\begin{tabular}{|c|c|c|c|c|c|c|c|c|}
\hline Year & Mouth & $\begin{array}{c}\text { Stomach- } \\
\text { liver }\end{array}$ & $\begin{array}{c}\text { Peritoneum, } \\
\text { intestines, } \\
\text { rectum }\end{array}$ & $\begin{array}{c}\text { Women's } \\
\text { sexual } \\
\text { organs }\end{array}$ & Breast & Skin & $\begin{array}{c}\text { Other: non- } \\
\text { specified }\end{array}$ & $\begin{array}{c}\text { Total } \\
\text { morbidity/ } \\
\text { mortality }\end{array}$ \\
\hline 1913 & 10 & 19 & 5 & 57 & 9 & 12 & 25 & 137 \\
\hline 1914 & 38 & 44 & 11 & 139 & 19 & 24 & 57 & 332 \\
\hline 1915 & 13 & 20 & 2 & 74 & 7 & 4 & 26 & 146 \\
\hline 1916 & 9 & 26 & 2 & 77 & 17 & 2 & 29 & 162 \\
\hline 1917 & 10 & 23 & 3 & 92 & 15 & 5 & 34 & 182 \\
\hline Total & 80 & 132 & 23 & 439 & 67 & 47 & 171 & 959 \\
\hline
\end{tabular}

Source: Boletín de Estadística de la Sociedad de Beneficencia Pública de Lima, 1913-1917

Table 3: Mortality of cancer cases at Sociedad de Beneficencia de Lima hospitals

\begin{tabular}{|c|c|c|c|c|c|c|c|c|}
\hline Year & Mouth & $\begin{array}{c}\text { Stomach- } \\
\text { liver }\end{array}$ & $\begin{array}{c}\text { Peritoneum, } \\
\text { intestines, } \\
\text { rectum }\end{array}$ & $\begin{array}{c}\text { Women's } \\
\text { sexual } \\
\text { organs }\end{array}$ & Breast & Skin & $\begin{array}{c}\text { Other: non- } \\
\text { specified }\end{array}$ & $\begin{array}{c}\text { Total } \\
\text { mortality }\end{array}$ \\
\hline 1913 & 3 & 11 & 0 & 17 & 2 & 1 & 9 & 43 \\
\hline 1914 & 3 & 19 & 1 & 21 & 5 & 0 & 15 & 64 \\
\hline 1915 & 5 & 17 & 1 & 22 & 0 & 2 & 10 & 57 \\
\hline 1916 & 2 & 15 & 1 & 25 & 1 & 1 & 13 & 58 \\
\hline 1917 & 5 & 16 & 3 & 19 & 3 & 1 & 10 & 57 \\
\hline Total & 18 & 78 & 6 & 104 & 11 & 5 & 57 & 279 \\
\hline
\end{tabular}

Source: Boletín de Estadística de la Sociedad de Beneficencia Pública de Lima, 1913-1917

To the founding surgeons of the SPC, the statistical visibility of cancer was vital but not sufficient. As the popularity of non-allopathic medicine reminded them, attitudes towards cancer also required socio-medical intervention to warn of the incidence of this disease and to convince the populace to place their trust in physicians. Ernesto Ruiz Rolando, who practiced at the Santa Ana hospital, exemplified this double imperative. He used estimates from the DSP between 1909 and 1918 to conclude that 1,090 cases of cancer had been diagnosed in the city of Lima during that period, the vast majority (738) uterine cancers. To buttress the authoritativeness of his accounting, he added that uterine cancers were also the most frequent form of the disease in Rio de Janeiro, and the second most common in Buenos Aires (after stomach/liver cancers) (Ruiz, 1920, p.71).

Doubling down on the surgeons' call to change widespread attitudes about cancer, Ruiz attacked lay and expert beliefs about the contagiousness of cancer, which stemmed from "the outsize fear and repugnance felt towards the cancer-afflicted and everything having to do with them" (Ruiz, 1920, p.75). Likewise, to counter popular notions about the relation 
between cancer and race, Ruiz divided cancer patients into "White," "Indian," "Mestizo," "Black," and "Yellow" categories and found no basis for the claim that Afro-Peruvians possessed some kind of immunity to the illness; although his statistics indicated that the rate of uterine cancers among "Indians" exceeded that of all other groups twofold, he believed that this proportion diminished significantly outside of Lima, implying that city life itself influenced the occurrence of cancer. While he discounted the role of race, Ruiz did identify a positive correlation between cancer and aging, but instead of emphasizing this finding he ultimately concluded that future research should primarily address the link between cancer and living conditions. Poverty and number of pregnancies (but not sexually transmitted infections) were among the conditions that Ruiz believed should be investigated as contributors to uterine cancer, based on his clinical experience.

Consistent with his critique of popular and medical misconceptions, Ruiz supported a public anti-cancer campaign led by specialists across Peru. In his view, the New York Obstetrical Society offered a good model when it widely distributed pamphlets that (1) emphasized the frequency of uterine cancer and its lethality if left untreated; (2) warned of cancerous signs, such as genital pain and discharges; and (3) exhorted women to overcome their fear of surgery, "as no other means, whether x-rays, radium, or electricity, can protect your health" (Ruiz, 1920, p.78). Such ideas would have been well-received by the SPC, which had included a Commission for Cancer Control since its inception in 1918.

The surgeon-led campaign against cancer occurred during a politically significant period, as Augusto B. Leguía rode a populist wave to the presidency in 1919 until his downfall in 1930. A successful businessman with ties to international financiers, Leguía believed that Peru's path to prosperity lay in its ability to attract capital, technology, markets, and business know-how from advanced capitalist Western countries, especially the United States, while rejecting the social conservatism of civilistas and wealthy landowners. His Patria Nueva modernization program featured a strong interventionist state to bolster rapid economic growth, especially in the export sector, launch major infrastructure-building projects, check the outbreak of epidemics, and revamp existing legislative frameworks with a new Constitution (1920) and Penal Code (1924) (Aguirre, 2005).

These early progressive changes matched the aspirations of the middle and working classes and indigenous groups that aided in Leguía's rise. The 1920 Constitution, for example, legally recognized indigenous communities; Leguía also backed advocacy organizations such as the Patronato de la Raza Indígena, while simultaneously supporting legislation to regulate the length of the work day and establish a minimum wage, industrial safety standards, and maternity leaves (Parker, 1998). Furthermore, in a move that secured support from a significant segment of young people at the Facultad de Medicina, Leguía proposed an overhaul of higher education that included mandatory retirement of faculty members at age 70 , limiting them to a single professorship, holding open contests for academic vacancies, and adding student representation in university administration (Perú, 1919). Although the dean from 1922 to 1931, Doctor Guillermo Gastañeta Espinosa, remained bitterly opposed to student representation in the academic council, Leguía's university reforms succeeded in renewing the roster of professors at the Facultad de Medicina; by 1934, only 8 of the 34 professors who held medical chairs in 1921 remained (Bustíos, 2006, p.124). 
The promise of progressive change during Leguía's early tenure frames the rise of the Liga Anti-Cancerosa, led by Juan José Mostajo. A 1913 graduate of the Facultad de Medicina, Mostajo made his case to the SPC in July 1918, asking surgeons for their support in launching a national cancer control campaign due to his "alarm over rising cancer morbidity and mortality." The SPC agreed and created a Cancer Control Commission, with Mostajo as president and Constantino T. Carvallo and Ricardo Palma as advisors. The commission swiftly moved to place ads in magazines and journals "to awaken the health awareness of individuals, without which the calls for early detection are chimerical" (Mostajo, 1945, p.1; Alzamora, 3 Jan. 1914).

The commissioners also penned open letters to generalist physicians, midwives, and the lay public. Generalist physicians were cast as pivotal allies of surgeons, since their advice determined "whether the sick person made the best decision," that is, to seek specialized surgical care. The group found that it was easier to influence these decisions when dealing with signs of cancer in the mouth rather than in women's genitals, given "the shame [female] patients feel about the physical examination, the repugnance physicians frequently show while performing gynecological exams, and their guarded optimism about postmenopausal bleeding, which they attribute to non-threatening disorders" (Sociedad..., 1926, p.21). According to the commissioners, all irregular genital bleeding was considered suspicious, and physicians were expected to deny these patients any drugs (including palliative ones) and instead direct them to seek surgical or gynecological attention.

In addressing midwives, the commissioners hoped they would be "loyal and effective collaborators" who would be willing to defer to physicians in anything other than births and puerperal care, "even if that meant loss of income." Asserting this group's presumed inferiority of knowledge and subordinate professional status, the commissioners urged midwives to avoid giving women advice about cancer and even treatments against pain and inflammation. Gynecology "is a medical science completely unknown to you, one in which you may not dabble without causing harm and usurping [another expert's jurisdiction]." In contrast, prompt referrals to medical care would produce "the noble satisfaction of knowing you have contributed to the welfare of society and the nation" (Sociedad..., 1926, p.26).

The commission's authoritarian tone towards midwives turned alarming in the letters addressed to the lay public, which described cancer as a deadly disease that could begin without pain and develop undetected by the patient. It was neither hereditary nor bloodborne, and it certainly was no cause for shame. Patients were advised to be wary of things such as intermenstrual bleeding, pain after sex, bumps under the skin, wounds that didn't heal, unexplained weight loss, persistent indigestion, and moles that changed color or appearance, as any of these could be a sign of cancer. Seeking relief through proprietary drugs or herbal remedies "meant suicide," but if caught and surgically excised early, cancer could be cured (Sociedad..., 1926, p.30).

The SPC's anti-cancer campaign had the kind of high visibility and technical novelty that captured Leguía's attention, and his administration wasted little time bringing it under the umbrella of the Patria Nueva. In February 1922, the DSP named Mostajo the "initiator of the campaign against cancer in Peru," and tasked him with studying "the organization and development of anti-cancer leagues in Europe and the U.S." (Sociedad..., 1926, p.19). 
Using his own funds, Juan José Mostajo left for a two-year voyage in 1922 to observe the organization of cooperative cancer control efforts between physicians, government offices, and civil society organizations, which included South American destinations Leguía did not anticipate. Mostajo visited Montevideo's Instituto del Radium and Hospital Maciel, which he called the "the most important oncological center in South America," noting that it attracted patients from as far as Chile; he also noted the surprise of his Uruguayan hosts at the scrappy vigor of the Peruvian public outreach campaign, which was lacking in that country (Mostajo, 1945, p.2).

After stops in Rio de Janeiro and Buenos Aires, Mostajo traveled to London, where he visited the Imperial Cancer Institute, the Radium Institute, and the Middlesex Hospital (Salomón, 14 July 1922). He and his wife also traveled to Germany, Italy, and France. Everywhere he went, he made a point to seek out and meet with experts who endorsed the idea that a broad alliance between physicians, civil society, and the government for early detection and treatment would be beneficial. Ferdinand Blumenthal of the Institute of Cancer Research in Berlin was one such figure, as were Marie Curie and Claudius Regaud of the Curie Institute, and even Pope Pious XI, who had been president of the Anti-Cancer League as Archbishop of Warsaw back in 1919. After his rewarding sojourn in New York City, where he toured Memorial Hospital, the Crocker Institute at Columbia University, and the Rockefeller Institute, Mostajo returned to Peru, confident that his accumulated experiences would help him appeal to the Peruvian government to make more deliberate contributions to the anti-cancer campaign (Mostajo, 1945, p.9).

Much had changed during Mostajo's two-year absence, however. The 1920s unleashed new forms of political activism that Leguía tried to but was unable to wholly control. His government turned increasingly authoritarian, countering the rise of the Third International-affiliated Socialist Party (founded by José Carlos Mariátegui), exiling the activist Víctor Raúl Haya de la Torre to Mexico (where he founded APRA), and quashing indigenous revolts in the south. Nevertheless, the president was still eager to support initiatives that burnished his regime's image as a model of expert-led modernization, as long as they did not challenge his authority; the anti-cancer campaign neatly fit the bill. With his colleagues Ricardo Palma and Alberto Sánchez Moreno, Mostajo established the Liga Anti-Cancerosa (Anti-Cancer League, LAC) in 1924, and affiliates in Chiclayo and Arequipa. The government officially recognized the LAC by executive decree in September 1926, and with a ceremony at the Teatro Colón in Lima. There Leguía's Minister of Development, Pedro José Rada y Gamio, emphasized Leguía's backing of the LAC and listed the government's other health care achievements, such as the establishment of syphilis dispensaries and its campaigns against tuberculosis, yellow fever, and smallpox. "There is no public health initiative," the minister declared, "that does not count on the determined and enthusiastic support of the President" (Reconocimiento, 1926, p.20).

Several notables joined the LAC's board, including Lima's Archbishop as well as its mayor, the director of the DSP, the director of the Beneficencia, and Leguía himself, who served as the LAC's honorary director. This was in addition to a Scientific Steering Committee led by the dean of the School of Medicine and the president of the SPC, and a Ladies' Committee that included philanthropists Juana Alarco and Mercedes Ayulo. Juan José Mostajo presided 
over this fledgling organization. At the LAC's inaugural event, Mostajo summarized the LAC's vision: cancer could be defeated, even if its etiology was not well understood, "with the strong support of public opinion and well-run sanitary efforts." Syphilis and yellow fever, in his opinion, had begun to be routed successfully this way (Sociedad..., 1926, p.6).

Encouraged by Leguía's patronage, Mostajo outlined a robust and original plan of action that went beyond the LAC's established information dissemination and public outreach functions. This comprised the creation of outpatient cancer clinics at the Hospital Loayza, Hospital Dos de Mayo, and Hospital Militar to diagnose, classify, and count - but not treat - cases of the illness. To further increase the visibility of the campaign against cancer, the LAC also proposed an annual "Cancer Week" to be observed nationwide, as well as the issuance of a cancer awareness postage stamp to raise funds. In addition, the LAC aimed to create a library with materials purchased at or donated by sister institutions in Europe and the Americas. The LAC's role as an information clearinghouse would also involve continuous production of up-to-date cancer statistics to be compiled and sent to generalist physicians. Finally, the LAC envisioned creating a corps of visitadoras sociales tasked with furthering propaganda efforts among the general population, assisting in the fight against charlatanism, following up on patients' compliance with physicians' orders, and bereavement support "in homes where there is no hope" (Mostajo, 1945, p.13). None of this came to pass; what appeared to be the moment of the LAC's take-off and Mostajo's triumph instead turned out to be the twilight of the LAC.

\section{The decline of the LAC}

The LAC began to wilt as soon as it bloomed, illustrating an important tension at the heart of the 1920s Peruvian anti-cancer initiatives, between the desirability and innovativeness of public engagement and the difficulty of finding an institutional home for such function. Leguía's opportunism led him to support several cancer-related tactics, some poorly planned and some underappreciated, that failed to strengthen the expertpublic-civil society partnership the LAC envisioned and pioneered. Meanwhile, the Facultad de Medicina under Dean Gastañeta progressively moved towards stressing the need for multiple forms of hospital-based cancer care, which diluted the influence of surgeon-led groups like the SPC and especially the non-hospital-based initiatives they spawned, such as the LAC. As a result, as Leguía's regime crumbled in the late 1920s the LAC could not find a ready institutional home for its ambitious program.

In 1924, the same year Mostajo founded the LAC, Leguía established the Instituto Nacional del Cáncer (INC) and appointed Doctor Eladio Lanatta as its director. It was a confusing decision, since the INC duplicated the LAC's work. In addition to specialized clinical sections, the INC included a Statistics and Propaganda section within its organization which was charged with gathering nationwide cancer statistics, organizing conferences and publications, as well as guiding educational efforts in consultation with the Asociación Nacional de Estudios contra el Cáncer (ANEC). The latter, which Leguía also set up in 1924, was an expert medical panel that included the dean of the Facultad de Medicina and the president of the Academia Nacional de Medicina, duplicating the role of 
the SPC's Cancer Control Commission. Though Leguía offered a 5,000-square-meter plot of land to build the INC headquarters, his administration failed to honor its commitment, which ensured that the INC and ANEC faded away quietly and quickly (Sociedad..., 1926).

Leguía also revamped the DSP, splitting it into two divisions: Epidemic and Contagious Illnesses, devoted to plague, smallpox, yellow fever, measles, and the flu, and Preventive Medicine and Hygiene, in charge of tuberculosis, malaria, venereal diseases, alcoholism, maternal-child care, and cancer. DSP Director Sebastián Lorente hailed this reorganization as a sign of Peru's "official incorporation to the worldwide struggle against cancer" at the first Pan-American Conference of Directors of Hygiene in Washington DC in 1926 (Lorente, 1926, p.645).

Even though Leguía pursued disparate cancer-control tactics, none matched the work the LAC was already doing on public outreach, with its involvement of public figures, inclusion of cities beyond Lima in leadership roles, and letters and lectures in workplaces and schools. Meanwhile, the Facultad de Medicina almost entirely overlooked the role of public outreach, even though the emphasis on cancer as being rooted in people's living conditions held sway through the 1920s. Experts such as Miguel Aljovín and Eladio Lanatta, for example, proposed gathering more thorough data about patients' occupations, number of pregnancies, places of birth, and drug habits to find out how these factors might be related to cancer. They also extolled access to simple diets and clean water as means to ward off the disease. Consistent with Beneficencia statistics, both continued to find uterine and stomach cancers most common, and they followed established practice in emphasizing surgery as the treatment of choice. Unfortunately, the majority of patients still arrived at the hospital when surgical treatment was futile, and were consequently only offered palliative treatments such as morphine, quinine, and bed rest (Aljovín et al., Dec. 1927; Lanatta, 1928).

In addition to physicians' continuing frustration over delayed patient diagnosis, publications from the late 1920s also signal important new organizational developments in cancer care. First, beds for cancer patients were scarce; this was true even in newly built academic institutions such as the Hospital Arzobispo Loayza, which fostered a culture of teamwork, thrift, and resource-sharing, especially between surgeons and gynecologists, strengthening the affinity between these specialties that started in the late nineteenth century and underscoring the expert opinion that understanding and treating cancer required multi-disciplinary involvement (Aljovín et al., Dec. 1927, p.4). Indeed, this trend expanded, and by the early 1930s several specialty courses in the Facultad de Medicina such as pathological anatomy, surgery, gynecology, otorhinolaryngology, and urology had been modified to incorporate cancer-related topics (Mckenie, 1932; Villarán, 1932; Aljovín, 1932; Denegri, 1932; Pazos, 1932).

These pedagogical and organizational developments accompanied new therapeutic approaches. Although surgery's grip over cancer remained strong even after Constantino T. Carvallo died in 1920, his replacement, Miguel Aljovín, a professor of gynecology from 1920 to 1934, presided as radiation therapy came of age. X-ray therapy had been introduced in Peru in 1897, with Carvallo importing the technology soon after it was invented. Yet in the 1920s its role in cancer care was secondary to surgery, mainly limited to previously- 
operated patients whose cancers returned (Aljovín et al., Dec. 1927). Likewise, Guillermo Gastañeta introduced radium in his private practice by 1917, a few years before he became dean of the Facultad de Medicina (Mostajo, 1945). In the late 1920s, Eladio Lanatta (1928, p.10) acknowledged that "some physicians own small amounts of radium," but added that "it is better not to take these into consideration," as the use of the substance demanded technical skill and the right infrastructure. It was the government's responsibility, he concluded, to invest in the facilities, training, and material resources to make hospitalbased radium therapy a reality. The medical yearning for this promising new technology inspired an invitation from the Facultad de Medicina to Claudius Regaud, director of the Curie Radium Institute in Paris. Diplomatically, Regaud commended the cooperative spirit taking hold in clinical cancer care in Peru and made it clear that radiologists "are not enemies of surgery," while avoiding any mention of cooperation with the LAC and its non-hospital-based mission (Regaud, 1929, p.85).

Despite the intentions of radium proponents, use of this technology remained limited to the Hospital Loayza in the turbulent late 1920s and early 1930s. Peru's economy had become dependent on foreign loans, and when the US stock market crashed the country's prosperity abruptly ended, even bankrupting the Banco de Perú y Londres, the nation's most important financial entity. Urban unemployment and wage reductions caused a recession that harmed manufacturers and agricultural producers, who abandoned Leguía while Socialist and APRA forces regrouped. In August of 1930, Colonel Luis Sanchez Cerro led a coup against Leguía, and the country was ruled by military forces for about a year; during this time property restrictions were removed as a prerequisite for the right to vote, which was extended to all literate men over age 21 (Klaren, 2000).

The military called for general elections for 1931. The victory of Colonel Luis Sanchez Cerro was marred by a persistent confrontation with APRA until his assassination in 1933, which prompted a coup by General Oscar Benavides (1933-1939). The first years of the 1930s were equally tumultuous at the Facultad de Medicina, with the resignation of Dean Guillermo Gastañeta in 1931 and the short-term appointment of two subsequent deans up to 1933 . Though violent confrontations between the military and APRA continued during the 1930s, the economy began a vigorous recovery led by exports. Meanwhile, the Facultad de Medicina entered a period of relative stability under Dean Carlos Villarán (1933-1939), when cancer care became concentrated in academic hospitals which accommodated new radiology specialists.

As early as 1928, clinicians at the Hospital Arzobispo Loayza were using an annex to the gynecology department exclusively for cancer patients. It was the first clinical unit dedicated to the disease in Peru, and a sign of how the statistical and clinical burden of women's cancers shaped approaches to this ailment in one of the newest and most advanced tertiary care institutions in the country (Año Universitario, 1934). Gynecology professor Miguel Aljovín managed to procure $79 \mathrm{mg}$ of radium from the Paris Radium Institute for the ward, and physicians came to deem radium therapy at least as effective as surgery against cervical cancers and more appealing to patients, given their persistent fear of the knife. Physicians at the Hospital Loayza developed procedures to improve the overall poor health of admitted cervical cancer patients before administering radium therapy, especially 
to clear pre-existing infections and curb symptoms of anemia. They also took biopsies, which were analyzed in-house to determine the extent of lesions (García, 1934).

By the early 1930s, physicians followed a careful routine when using radium against cervical cancer to protect patients and themselves from the risk of burns. The patients' reproductive organs were irradiated over several days with break periods, yielding almost immediate results. "It is truly wonderful to see how enormous tumors shrink and are cleansed," wrote Doctor Pedro García Portocarrero, "retreating quickly until the appearance becomes almost normal." When radium was used pain almost always subsided, and patients' weight and appetite improved in the short term, but complete and permanent removal of cancerous lesions was elusive. For example, of 159 patients García treated for cervical cancer, 70 received radium alone, 29 underwent radical hysterectomies, 7 got both kinds of treatment, while 20 were treated with "other" therapies and 33 received no treatment at all. After five years, García (1934, p.78) could only be certain that 4 patients remained alive. Interestingly, this suggests that physicians had begun to use the 5-year remission period as a proxy for a "cancer cure;" more importantly, it shows that losing touch with patients was so common that offering them follow-up care would have been difficult, let alone evaluating treatment efficacy over time. Furthermore, it is clear that a significant proportion of patients still chose therapeutic paths aside from surgery and radiation, although it is not easy to ascertain what those might have been.

Despite these challenges, or perhaps because of them, state and academic entities during Oscar Benavides's regime were finally converging on the need to give hospital-based cancer care a significant boost. In February 1935, the government levied a tax on the commercial use of ice and electric refrigeration to fund a new Department of Gynecology and Cancer at the Facultad de Medicina, founded the year before and directed by Doctor Javier Márquez, who trained in Paris with Claudius Regaud (Perú, 1935a; Mostajo, 12 Dec. 1934). In October 1935, Benavides established the Ministry of Public Health, Work, and Social Welfare, giving more autonomy to the increasingly specialized health bureaucracy of the DSP (Perú, 1935b). A few months later, Sociedades de Beneficencia nationwide were reorganized, with more funding and a renewed mandate to support hospital administration (Perú, 1935c).

The Beneficencia used its new monies to purchase one gram of radium for the Hospital Loayza, as well as to build new installations to store the substance safely. The Beneficencia also agreed (in exchange for an operating fee) to expand the hospital's electric grid to power a new radiotherapy machine that the Facultad de Medicina had bought from Siemens in Berlin (Sociedad..., 20 Feb. 1936; Beneficencia..., 16 Aug. 1936). In addition, the Facultad de Medicina purchased press coverage from La Prensa to broadcast its cancer-related projects as well as other hospital infrastructure-building projects in Lima (De la Fuente, 18 July 1938).

The long wait for a specialized cancer hospital ended in May 1939, when Benavides re-launched the Instituto Nacional del Cáncer (INC), which Leguía established but never funded. A dependency of the Ministry of Public Health, Work, and Social Welfare, the INC would be dedicated to studying and preventing the disease, training clinicians, and providing patient care. Revenue from the ice and commercial/industrial refrigeration taxes, as well as from an older Leguía-age tax on imported pharmaceuticals, would fund the INC (Perú, 1939a, 1939b, 1926). Insurance pensions and direct payments for clinical services 
were to provide additional revenue, but the INC destined $70 \%$ of its beds for patients who could not afford care, acknowledging the poverty of many cancer patients. In his press announcement, Minister of Health Guillermo Almenara indicated that each year cancer afflicted 4 out of 1,000 Peruvians. In his opinion, this number was bound to climb with more people seeking care. To address this surge, the INC was to be located in a 6-floor facility covering 7,600 square meters and accommodating 113 beds, complete with a library and housing for nurses and physicians (Almenara, 15 May 1939).

The INC spelled the end of the LAC. For starters, Almenara pointedly did not acknowledge it in his official announcement, even though he paid homage to the defunct ANEC. More importantly, he said that one of the INC's responsibilities would be to "assist the executive government in an intense social campaign against cancer," thus signaling that public outreach would be handled directly by the central government through the INC from 1939 on (Perú, 1939a, p.1). This level of centralization did not make sense to all clinicians, who believed para-medical civil society agencies had a role to play in coordination with (yet separate from) the INC, raising funds, spreading the gospel of early detection, and providing insights as to why people at risk for cancer failed to turn up for check-ups. In their opinion, these functions were better suited to the skills of entities such as the LAC rather than clinical care providers (Mattos, 1941; Holguín, 1940). But given the power wielded by the new Ministry of Public Health, buttressed by the trend to treat cancer care as a hospital-bound matter, it was the INC that had the upper hand.

Mostajo did not just let the Ministry of Health sideline the institution he had painstakingly built. With the clock ticking towards the formal inauguration of the INC, which opened its doors in September 1940, the LAC joined forces with the newly formed Pan-American League against Cancer, an organization founded in New York to promote international efforts against the disease through publications, statistics, study-abroad scholarships, and conferences. Francis Carter Wood of Columbia University and Angel Roffo of the Instituto de Medicina Experimental in Buenos Aires co-led the Pan-American League against Cancer and named Mostajo its vice-president. In July 1941, Mostajo arranged a visit by Wood. Ever the skilled cheerleader and networker, Mostajo got the backing of Lima's mayor, the Rotary Club president, the Peruvian Society of Otorhinolaryngology, the dean of dentistry, the police and military health associations, and the National Council of Women (Mostajo, 1945). Mostajo also wrote to the dean of the Facultad de Medicina, Carlos Monge Medrano, to solicit support for Wood's visit and announce the forthcoming First Pan-American Cancer Congress, which was to be held in Buenos Aires the following year (Mostajo, 10 July 1941).

At the time, Mostajo had reason to hope the LAC might withstand the rise of the INC. In 1939 Peru elected a new President, Manuel Prado y Ugarteche, who in turn appointed a new Minister of Health, Constantino J. Carvallo; this minister was the son of the famous Constantino T. Carvallo, a gynecologist who (unlike Almenara) was a friend to Mostajo. In fact, Mostajo went as far as to nominate the younger Carvallo to the council of the Pan-American League against Cancer. This bold appeal to a prestigious and well-connected international patron turned out to be Mostajo's last move. A few days after sending his letter to Dean Monge, the Ministry of Health annulled the LAC via 
ministerial decree (Mostajo, 1945, p.21). Furthermore, in an unprecedented medical title grab, Carvallo appointed himself the INC's first director and served in that capacity and as Minister of Health until 1945, while also occupying the professorship of gynecology that his father once held.

\section{Starting over}

Politically, in the early 1940s the balance of forces had decidedly shifted towards treating all cancer care as a state-directed and hospital-bound matter, which made a non-hospital partnership of government, medical, and civil society actors such as the LAC irrelevant at best and a competitor of the INC at worst. To complicate the situation further, in 1942 the INC was renamed the Instituto Nacional de Radioterapia (INR), an acknowledgment of the power held by radiotherapy specialists at the new institution, eclipsing the balance that previously existed between different forms of clinical involvement (particularly surgery). An affronted and betrayed Mostajo (1945, p.23) noted bitterly how workers replaced the name on the front of the building, "as if it were a commercial establishment."

Yet, for all the attributions of the INR, it did not improve on the LAC's outreach initiatives but rather rehashed them, while failing to draw on the accumulated expertise of the LAC's surgical organizers, its influential partners in civil society, and its international collaborators. As a result, the INR's public outreach function was simultaneously unoriginal and diminished, buried in the medical bureaucracy of its Prophylaxis and Propaganda section. Charged with reaching both the general public and generalist physicians, this section copied the LAC's modus operandi with pamphlets such as "What Must Be Known about Cancer," "Current State of Gastroscopy in Clinical Settings," "What Must Be Known about Cervical Cancer," "What Every Person Must Know about Breast Cancer," and "What Must Be Considered When Sending a Biopsy to the National Radiotherapy Institute" (Instituto..., 1942-1944). But it stopped far short of engaging civic leaders, extending its footprint beyond Lima, raising extramural funds, kindling collaborations with Peru's neighbors, or building up a corps of visitadoras sociales, as the LAC had either done or planned to do. The INR's centralization thus squandered a significant amount of the efforts expended by the SPC's cancer control pioneers since the 1920s.

Doctor Julio Bedoya Paredes, a radiologist at the INR, nonetheless wrote that the Prophylaxis and Propaganda section succeeded in increasing demand for the INR's services, an assertion that was picked up and repeated by the Pan-American Sanitary Office in 1945, which credited the INR with conducting "an extensive educational campaign" (Oficina..., July 1945, p.20; Bedoya, 1944). That year, however, a new director took over the INR. The radiologist Oscar Soto gently disabused his more sanguine colleagues of their notions about the effectiveness of centralized hospital-based outreach (which had not managed to make inroads among patients with treatable cancers) or changing the behavior of clinicians to promptly refer patients to the INR instead of attempting to treat these patients by themselves. Between 1943 and 1947, Soto (1948) noted the majority of the 30,181 patients seen at the INR were very advanced cases, just as they had been earlier. He pleaded for the INR's 97 beds to be doubled in order to create an "incurable" charity ward (p.633). 
Considering this state of affairs, Soto underscored the importance of establishing alliances with non-hospital civil society partners to publicize the importance of early detection among lay people and physicians alike, just as Mostajo and the SPC had done before. The Women's Field Army of the American Society for the Control of Cancer and Cuba's Liga Contra el Cáncer stood as examples for Peru, in Soto's opinion. But what about the LAC? According to Soto, its decline had been all but guaranteed when a cancer hospital was not built in the 1920s. "A league without a hospital," he sentenced, "will end up fading, with disillusioned patients unable to get care tuning out the league's message. A hospital without a league condemns the hospital to keep on treating advanced cases and to yield extremely low rates of cure, which in turn makes the public lose faith in treatment and turn away from the hospital" (Soto, 1948, p.624).

Soto's appraisal of the history of the LAC's demise sidestepped the controversial political dismissal of the LAC by the Ministry of Health's centralize-and-hospitalize strategy, while simultaneously avoiding overtures to former LAC leaders and failing to reignite the local and international professional collaborations the LAC set in motion and the INC/INR under Carvallo had abandoned. Soto announced negotiations with the Ministry of Health to launch a new medical/government/civil society partnership, the Liga contra el Cáncer, sponsored by the Sociedad Peruana de Radiología and led by Julio Bedoya Paredes. Without a trace of irony, Soto (1948, p.632) added that "it is our well-founded hope that success will crown our efforts."

The tendency to write off the past plagues clinical and public health discussions to this day. The Liga contra el Cáncer that finally emerged in the 1950s did not acknowledge any ties with the 1920s LAC, despite their identical public engagement missions (Liga..., 2020). More recently, a 2017 editorial in The Lancet Oncology declared that Peru had finally taken "a first step" to reduce its cancer burden with its 2013 Plan Esperanza for comprehensive cancer care and prevention (Coburn et al., 2017). The editorial made no mention of either of the leagues, nor of the creation of the INC/INR in 1939 (which was subsequently renamed the Instituto Nacional de Enfermedades Neoplásicas when Soto stepped down as director in 1952), nor of the adoption of cervical cancer screening as part of the maternal health program in the 1960s (Necochea López, 2016, p.110). Just a few years before the abovementioned editorial, a Harvard-led Global Task Force on Expanded Access to Cancer Care and Control in Developing Countries issued a "call to action," predicated on the need to learn from previous initiatives, "including those designed to address Aids, tuberculosis (including multidrug-resistant tuberculosis), maternal and child health, maternal mortality, sexual and reproductive health, and mental health" (Farmer et al., 2010, p.1187). But it made no mention of previous initiatives for cancer care and control originating in the Global South. The reality is that Latin American nations were taking steps to publicize the threat of cancer as early as the 1910s, and began to offer clinical care, pioneered and debated the use of technologies such as radium and colposcopy, and even formulated national cancer policies between the 1920s and the 1930s. In other words, today's programs, policies, and collaborations related to cancer care are hardly being built on virgin soil. 
As for the rise of Peru's cancer control public outreach, the availability of hospital statistics and the willingness among surgeons to claim an old illness's many manifestations (but especially those in the female reproductive organs) as part of their professional jurisdiction were more determinant than the support of state health agencies. In fact, cancer control in early twentieth-century Peru involved government health organizations only modestly, given their fledgling status and their overriding interest in general sanitation and epidemic diseases. Under these circumstances, professional medical societies and individual physicians directed the first cancer control efforts in the country beginning in the 1910s, distributing educational pamphlets, railing against non-allopathic healers, and seeking input and support from civic leaders in Lima, across the country, and internationally. This latter group is especially important in this case, as it shows the extent to which Latin American anti-cancer activists were drawn to examples besides the US and Western Europe, as they traveled to other Latin American institutions, compared statistics with their neighbors, and exchanged training resources. In other words, the emergence and development of anti-cancer activism includes features that cannot be studied in national isolation but rather must be seen as emerging from transnational discussions with dispositions and knowledges spanning the entire region. Peru's LAC leaned on these connections during its embattled last days, but to no avail. By the late 1930s, the decade-long movement towards hospital-based cancer treatment, coupled with the political power of the novel INC, disrupted the balance between surgical and radiological specialties and ultimately wiped out the LAC.

It is important to note that outreach practices in cancer care, even those enacted by the INC, did not amount to a break with prevalent ways to deal with disease. In fact, Peruvian cancer care advocates through the 1930s believed a campaign against cancer could succeed using the same public education and decentralized services model taken from existing campaigns against diseases such as syphilis and yellow fever. Although incurable at that time, these diseases had been beaten back by improved sanitation, cooperation from the public, and medical therapies. In the eyes of cancer care advocates, cancer was susceptible to the same multi-pronged population health strategy that civilized nations were expected to embark on, and one that could also help increase the population or "human capital," a cherished goal of Latin American nations since the eighteenth century.

The medical historiography is very clear about the attention and resources Latin Americans devoted to illnesses such as tuberculosis, plague, smallpox, and yellow fever in the pursuit of demographic gains (Quevedo et al., 2004; Palmer, 2003; Hochman, 1998; Cueto, 1997). Yet, as this case establishes, there were health experts, medical educators, and political administrators who also saw cancer as a significant challenge to healthy population growth. This finding complements the historiography about the social and medical priorities of Latin American nations during the early twentieth century by showing that our public health concerns were not limited to infectious diseases at that time. Cancer, malnutrition, and mental illness were objects of intense interest in various countries (Pohl Valero, 2014; Ríos Molina, 2016), and all threatened national vitality. Exploring how these health-related matters became broad public problems can shed new light on the history of what we now commonly label "chronic illnesses." 


\section{ACKNOWLEDGEMENT}

Research for this project was possible thanks to a grant from the Gerda Henkel Foundation, which I gratefully acknowledge. Archived materials come from the Archivo del Museo de Ciencias de la Salud, Universidad Nacional Mayor de San Marcos. Many thanks to archivist/librarian Ms. Ruth Guerrero for her expert assistance locating materials.

\section{NOTE}

${ }^{1}$ The Sociedad de Beneficencia de Lima was established in 1834 to run all public charitable establishments in the city, including hospitals. Well-heeled members of Lima society, including women, were conspicuous in the management of this organization during the early twentieth century.

\section{REFERENCES}

ACADEMIA...

Academia Peruana de Cirugía. Estatuto y reglamento. Lima: APC. 1984.

ADVERTISEMENT.

Advertisement. El Perú Ilustrado, v.133, p.997. 23 Nov. 1889a.

\section{ADVERTISEMENT.}

Advertisement. El Perú Ilustrado, v.134, p.1025. 30 Nov. 1889 b.

\section{AGUIRRE, Carlos.}

The criminals of Lima and their worlds: the prison experience, 1850-1935. Durham: Duke University Press. 2005.

\section{ALJOVIN, Miguel.}

Cátedra de Ginecología. Serie Documentos Recibidos, caja 17, archivador 57 (Archivo del Museo de Ciencias de la Salud de la Universidad Nacional Mayor de San Marcos, Lima). 1932.

ALJOVIN, Miguel et al.

Apuntes para el estudio del cáncer en nuestros servicios hospitalarios. Serie Folletos 02280 (Archivo del Museo de Ciencias de la Salud de la Universidad Nacional Mayor de San Marcos, Lima). Dec. 1927.

ALMENARA, Guillermo.

Los problemas del cáncer serán resueltos directamente por el Estado. La Reforma Médica, p.437-438. 15 May 1939.

\section{ALZAMORA, L.}

Carta al Decano de la Facultad de Medicina. Serie Documentos Recibidos, caja 11, archivador 39 (Archivo del Museo de Ciencias de la Salud de la Universidad Nacional Mayor de San Marcos, Lima). 3 Jan. 1914.

ANDRADE, Rômulo de Paula et al. Médicos, viagens e intercâmbio científico na institucionalização do combate ao câncer no Brasil (1941-1945). História, Ciências, SaúdeManguinhos, v.17, supl.1, p.109-126. 2010.
AÑO UNIVERSITARIO.

Año Universitario. Serie Documentos Recibidos, caja 18, archivador 59 (Archivo del Museo de Ciencias de la Salud de la Universidad Nacional Mayor de San Marcos, Lima). 1934.

ARONOWITZ, Robert.

Unnatural history: breast cancer and American society. Cambridge: Cambridge University Press. 2007.

\section{BASTIAN, J.}

Cura radical del cáncer del cuello uterino por la vía abdominal. La Crónica Médica, v.16, n.252, p.189-192. 1899.

BEDOYA, Julio.

La campaña anticancerosa en el Perú. Boletín de la Oficina Sanitaria Panamericana, v.23, n.8, p.695-698. 1944.

\section{BENEFICENCIA...}

Beneficencia Pública de Lima. Autorización a la Facultad de Ciencias Médicas de la UNMSM. Serie Documentos Recibidos, caja 18, archivador 61 (Archivo del Museo de Ciencias de la Salud de la Universidad Nacional Mayor de San Marcos, Lima). 16 Aug. 1936.

BUSCHINI, José.

La conformación del cáncer como objeto científico y problema sanitario en la Argentina de principios del siglo XX: discursos, prácticas experimentales e iniciativas institucionales (1903-1922). Historia, Ciências, Saúde Manguinhos, v.21, n.2, p.457-475. 2014.

BUSTIOS, Carlos.

Educación médica y su contexto: Facultad de Medicina de San Fernando, Perú: 1856-1969. Lima: Universidad Nacional Mayor de San Marcos. 2006.

CANTOR, David (Ed.).

Cancer in the twentieth century. Baltimore: Johns Hopkins University Press. 2008. 
CARRILlO, Ana María.

Entre el "sano temor" y el "miedo irrazonable". História, Ciências, Saúde - Manguinhos, v.17, supl.1, p.89-107. 2010.

CARVALLO, Constantino T.

Certificado médico de la Srta. Delia Rodríguez. Serie Documentos Recibidos, caja 11, archivador 39 (Archivo del Museo de Ciencias de la Salud de la Universidad Nacional Mayor de San Marcos, Lima). 22 Aug. 1914.

CARVALLO, Constantino T.

Carta al Decano de la Facultad de Medicina. Serie Documentos Recibidos, caja 8, archivador 31 (Archivo del Museo de Ciencias de la Salud de la Universidad Nacional Mayor de San Marcos, Lima). 6 Dec. 1906.

CARVAllO, Constantino T.

Carta al Decano de la Facultad de Medicina. Serie Documentos Recibidos, caja 8, archivador 30 (Archivo del Museo de Ciencias de la Salud de la Universidad Nacional Mayor de San Marcos, Lima). 11 Dec. 1905.

CARVAllO, Constantino $\mathrm{T}$.

Operaciones llevadas a cabo en la clínica de ginecología. Serie Documentos Recibidos, caja 6, archivador 25 (Archivo del Museo de Ciencias de la Salud de la Universidad Nacional Mayor de San Marcos, Lima). 19 Dec. 1898.

COBURN, Cassandra et al.

Cancer in Peru: a detailed examination. The Lancet Oncology, v.18, n.10, p.1300-1301. 2017.

CUETO, Marcos.

El regreso de las epidemias. Lima: IEP. 1997.

CUPERSCHMID, Ethel et al.

Instituto de Radium de Minas Gerais: vanguarda da radioterapia no Brasil, 1923-1935. História, Ciências, Saúde - Manguinhos, v.21, n.4, p.12351260. 2014.

DE LA FUENTE, Germán.

Carta al Dr. Sergio Bernales. Serie Documentos Recibidos, caja 19, archivador 63 (Archivo del Museo de Ciencias de la Salud de la Universidad Nacional Mayor de San Marcos, Lima). 18 July 1938.

DENEGRI, Juvenal.

Cátedra de Otorrinolaringología. Serie

Documentos Recibidos, caja 17, archivador 57

(Archivo del Museo de Ciencias de la Salud de

la Universidad Nacional Mayor de San Marcos, Lima). 1932.

DENEGRI, Juvenal.

Tratamiento quirúrgico moderno del cáncer de la lengua. La Crónica Médica, v.24, n.434, p.1832. 1907.
DENEGRI, Juvenal.

Del tratamiento quirúrgico de los fibromiomas uterinos. Tesis (Doctor in Medicine) - Universidad Nacional Mayor de San Marcos, Lima. 1895.

ERASO, Yolanda.

Controlling female cancer in Argentina: divergent initiatives and the road to fragmentation. Dynamis, v.34, n.1, p.73-100. 2014.

ERASO, Yolanda.

Migrating techniques, multiplying diagnoses:

the contribution of Argentina and Brazil to early detection policy in cervical cancer. História, Ciências, Saúde - Manguinhos, v.17, supl.1, p.3351. 2010.

FARMER, Paul, et al.

Expansion of cancer care and control in countries of low and middle income: a call to action. Lancet, v.376, n.9747, p.1186-1193. 2010.

GARCIA, Pedro.

El tratamiento del cáncer del cuello uterino por el radium. Tesis (Bachiller in Medicine) Universidad Nacional Mayor de San Marcos, Lima. 1934.

GARCIA CALDERON, Francisco.

Oficio. Serie Documentos Recibidos, caja 6, archivador 25 (Archivo del Museo de Ciencias de la Salud de la Universidad Nacional Mayor de San Marcos, Lima). 22 June 1897.

GARDNER, Kirsten.

Early detection: women, cancer, and awareness campaigns in twentieth-century United States. Chapel Hill: University of North Carolina Press. 2006.

GRAÑA, Alejandro.

Consideraciones históricas sobre la evolución de la ginecología. Ginecología y Obstetricia, v.47, n.4, p.238-249. 2001.

HOCHMAN, Gilberto.

A era do saneamento: as bases da política de saúde pública no Brasil. São Paulo: Hucitec; Anpocs. 1998.

HOLGUIN, Julio César.

La demografía del cáncer en Lima. Tesis (Bachiller in Medicine) - Universidad Nacional Mayor de San Marcos, Lima. 1940.

INSTITUTO...

Instituto Nacional de Radioterapia. Pamphlets. Serie Folletos (Archivo del Museo de Ciencias de la Salud de la Universidad Nacional Mayor de San Marcos, Lima). 1942-1944.

JOUVE, José.

The black doctors of colonial Lima: science, race, and writing in colonial and early republican 
Peru. Montreal: McGill-Queen's University Press. 2014.

KLAREN, Peter.

Peru: Society and nationhood in the Andes. New York: Oxford University Press. 2000.

LANA, Vanessa.

Organização da especialidade médica e controle do câncer do colo do útero no Brasil: o Instituto de Ginecologia do Rio de Janeiro em meados do século XX. História, Ciências, SaúdeManguinhos, v.23, n.3, p.683-701. 2016.

LANATTA, Eladio.

Algunas consideraciones sobre el cáncer en el Perú. Serie Folletos 01273 (Archivo del Museo de Ciencias de la Salud de la Universidad Nacional Mayor de San Marcos, Lima). 1928.

LIGA...

Liga Contra el Cáncer. Available at: <https:// ligacancer.org.pe/>. Access on: 29 July 2020. 2020 .

LORENTE, Sebastián.

La organización de los servicios sanitarios en el Perú. Boletín de la Oficina Sanitaria Panamericana, v.5, n.12, p.619-656. 1926.

MATTOS, Napoleón.

Consideraciones estadísticas, clínicas y terapéuticas de 221 casos de cáncer cérvico-uterino. Tesis (Bachiller in Medicina) - Facultad de Medicina, Universidad Nacional Mayor de San Marcos, Lima. 1941.

MCKENIE, Daniel.

Cátedra de Anatomía Patológica. Serie Documentos Recibidos, caja 17, archivador 57 (Archivo del Museo de Ciencias de la Salud de la Universidad Nacional Mayor de San Marcos, Lima). 1932.

MEJÍA, Marietta.

Del rincón de las cancerosas a la medicina experimental en el Hospital San Juan de Dios de Bogotá. Tesis (PhD in History) - Pontificia Universidad Javeriana, Bogotá. 2008.

MIMBELA, Pablo.

Clínica quirúrgica del Hospital Santa Ana. Anales de la Facultad de Medicina, v.8, p.213-223. 1922.

MOSCUCCI, Ornella.

Gender and cancer in England, 1860-1948.

London: Palgrave MacMillan. 2016.

MOSTAJO, Juan José.

Historia de la lucha contra el cáncer en el Perú. Serie Folletos (Archivo del Museo de Ciencias de la Salud de la Universidad Nacional Mayor de San Marcos, Lima). 1945.
MOSTAJO, Juan José.

Carta al Decano de la Facultad de Medicina. Serie Documentos Recibidos, caja 19, archivador 66 (Archivo del Museo de Ciencias de la Salud de la Universidad Nacional Mayor de San Marcos, Lima). 10 July 1941.

MOSTAJO, Juan José.

Carta a Carlos Villarán. Serie Documentos Recibidos, caja 18, archivador 59 (Archivo del Museo de Ciencias de la Salud de la Universidad Nacional Mayor de San Marcos, Lima). 12 Dec. 1934.

NECOCHEA LÓPEZ, Raúl.

La planificación familiar en el Perú del siglo XX. Lima: IEP; UNFPA. 2016.

ODRIOZOLA, Ernesto.

Duodécima lección. Gaceta de los Hospitales, v.2, n.49, p.556-560. 1905.

OFICINA...

Oficina Sanitaria Panamericana. Scientific institutions in Latin America, part II. Serie Folletos 05178 (Archivo del Museo de Ciencias de la Salud de la Universidad Nacional Mayor de San Marcos, Lima). July 1945.

PALMA, Patricia.

Sanadores inesperados: medicina china en la era de migración global (Lima y California, 18501930). História, Ciências, Saúde - Manguinhos, v.25, n.1, p.13-31. 2018.

PALMER, Steven.

From popular medicine to medical populism: doctors, healers and public power in Costa Rica, 1800-1940. Durham: Duke University Press. 2003.

PARKER, David.

The idea of the middle class: white-collar workers and Peruvian society, 1900-1950. University Park: Pennsylvania State University Press. 1998.

PAZOS, Ramón.

Cátedra de Vías Urinarias. Serie Documentos Recibidos, caja 17, archivador 57 (Archivo del Museo de Ciencias de la Salud de la Universidad Nacional Mayor de San Marcos, Lima). 1932.

PERU.

Ley 8.892: creando el Instituto Nacional del Cáncer. 1939a.

PERU.

Ley 8.946: modificando la ley 7.985 en el sentido de crear el impuesto a la producción de frío artificial. 1939b.

PERU.

Ley 7.985: creando el impuesto al hielo y a los aparatos refrigeradores eléctricos. 1935a. 
PERU.

Ley 8.124: creando el Ministerio de Salud Pública, Trabajo y Previsión Social. 1935b.

PERU.

Ley 8.128: reorganización de las Sociedades de Beneficencia Pública. 1935c.

PERU.

Ley 5.604: mandando construir un policlínico en la Facultad de Medicina de Lima. 1926.

PERU.

Ley 4.004: provisión de cátedras en las universidades de la república. 1919.

POHL VALERO, Stefan.

La raza entra por la boca: energy, diet and eugenics in Colombia, 1890-1940. Hispanic American Historical Review v.94, n.3, p.455-486. 2014.

QUEVEDO, Emilio et al.

Café y gusanos, mosquitos y petroleo: el tránsito desde la higiene hacia la medicina tropical y la salud pública en Colombia, 1873-1953. Bogotá: Universidad Nacional de Colombia. 2004.

RABI CHARA, Miguel.

Sociedad de Beneficencia de Lima Metropolitana:

172 años de historia. Lima: Sociedad de

Beneficencia de Lima Metropolitana. 2006.

\section{RECONOCIMIENTO.}

Reconocimiento. Liga Anticancerosa del Perú. Serie Folletos 06863 (Archivo del Museo de Ciencias de la Salud de la Universidad Nacional Mayor de San Marcos, Lima). 1926.

REGAUD, Claudius.

Algunos problemas actuales de cancerología. Anales de la Facultad de Medicina, v.15, p.82-98. 1929.

RIOS MOLINA, Andrés.

Cómo prevenir la locura: psiquiatría e higiene mental en México, 1934-1950. Ciudad de México: Universidad Nacional Autónoma de México. 2016.

RUIZ, Ernesto.

El cáncer del útero en Lima. Anales de la Facultad de Medicina, v.6, p.64-78. 1920.
SALOMÓN, Oscar.

Carta al Decano de la Facultad de Medicina. Serie Documentos Recibidos, caja 13, archivador 47 (Archivo del Museo de Ciencias de la Salud de la Universidad Nacional Mayor de San Marcos, Lima). 14 July 1922.

SAN, Chau San.

A la Prefectura de Lima. Serie Documentos Recibidos, caja 11, archivador 39 (Archivo del Museo de Ciencias de la Salud de la Universidad Nacional Mayor de San Marcos, Lima). 22 Aug. 1914.

SOCIEDAD...

Sociedad de Beneficencia Pública de Lima. Carta al Dr. Carlos Villarán. Serie Documentos Recibidos, caja 18, archivador 61 (Archivo del Museo de Ciencias de la Salud de la Universidad Nacional Mayor de San Marcos, Lima). 20 Feb. 1936.

SOCIEDAD...

Sociedad Peruana de Cirugía. La lucha contra el cáncer en el Perú. Serie Folletos 03536 (Archivo del Museo de Ciencias de la Salud de la Universidad Nacional Mayor de San Marcos, Lima). 1926.

SOTO, Oscar.

Sobre algunos aspectos del problema del cáncer entre nosotros. Revista Médica Peruana, v.20, n.238, p.613-640. 1948.

TEIXEIRA, Luiz Antonio et al. Imperfect tools for a difficult job: Colposcopy, "colpocytology," and screening for cervical cancer in Brazil. Social Studies of Science, v.41, n.4, p.585-608. 2011.

TEIXEIRA, Luiz Antonio et al. De doença desconhecida a problema de saúde pública: o Inca e o controle do câncer no Brasil. Rio de Janeiro: Ministério da Saúde. 2007.

VILLARAN, Carlos.

Cáncer del seno. Gaceta de los Hospitales, v.3, n.58, p.63-64. 1906.

VILLARAN, Carlos.

Cátedra de Clínica Quirúrgica. Serie Documentos Recibidos, caja 17, archivador 57 (Archivo del Museo de Ciencias de la Salud de la Universidad Nacional Mayor de San Marcos, Lima). 1932. 